\title{
Aspirin and metformin exhibit antitumor activity in murine breast cancer
}

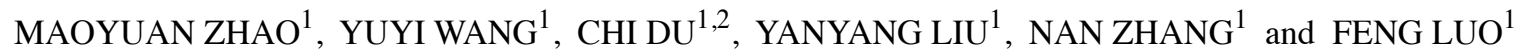 \\ ${ }^{1}$ Department of Medical Oncology, Lung Cancer Center, Cancer Center and State Key Laboratory of Biotherapy, \\ West China Hospital of Sichuan University, Chengdu, Sichuan 610041; ${ }^{2}$ Department of Oncology, \\ The Second People's Hospital of Neijiang, Neijiang, Sichuan 641000, P.R. China
}

Received July 4, 2017; Accepted December 29, 2017

DOI: $10.3892 /$ or.2018.6190

\begin{abstract}
Studies have shown that aspirin and metformin play important roles in chemoprevention and repression of breast cancers, even though the exact mechanism remains unclear. Aspirin is capable of stimulating apoptosis through prostaglandin-dependent or prostaglandin-independent pathways. Metformin inhibits cell growth by enhancing the tumor suppressive function of transforming growth factor (TGF- $\beta$ ). In the present study, we report a new link between aspirin, metformin, TGF- $\beta 1$ and murine breast cancer inhibition. Specifically, we showed that aspirin and metformin enhanced 4T1 cell apoptosis by inducing secretion of TGF- $\beta 1$, whereas estradiol weakened the effect.
\end{abstract}

\section{Introduction}

Traditionally, patients with type 2 diabetes mellitus and cardiovascular diseases are treated with aspirin and metformin (1-3). In recent years, both drugs have been reported to decrease the risk of several types of cancers, including breast cancer (4-10).

Aspirin, acetylsalicylic acid, has a wide range of uses, such as an analgesic, antipyretic and anti-inflammatory agent (11). As a nonsteroidal anti-inflammatory drug and cyclooxygenase (COX) inhibitor, aspirin prevents breast tumorigenesis in humans (12). The COX pathway plays an important role in

Correspondence to: Dr Feng Luo, Department of Medical Oncology, Lung Cancer Center, Cancer Center and State Key Laboratory of Biotherapy, West China Hospital of Sichuan University, 37 Guo Xue Xiang, Chengdu, Sichuan 610041, P.R. China

E-mail: luofeng@medmail.com.cn

Abbreviations: COX, cyclooxygenase; E2, estradiol; ELISA, enzyme-linked immunosorbent assay; ER, estrogen receptor; HER-2, human epidermal growth factor receptor 2, ErbB-2; PI, propidium iodide; pSmad2, phosphorylated Smad2; pSmad3, phosphorylated Smad3; miR, microRNA; TGF- $\beta$, transforming growth factor- $\beta$

Key words: aspirin, metformin, TGF- $\beta 1$, breast cancer, growth inhibition, estradiol cellular proliferation, migration and invasiveness $(13,14)$. However, the precise mechanism accounting for a possible anti-neoplastic action of aspirin is not clear. A recent study showed that small interfering RNA-mediated inhibition of the Smad signaling pathways decreases transforming growth factor (TGF)- $\beta 1$-induced COX-2 expression (15). Thus, there may be connection between aspirin and TGF- $\beta$.

Metformin (1,1-dimethylbiguanide) is the most widely prescribed drug to treat type 2 diabetes mellitus, notably in overweight or obese individuals $(16,17)$. Recently, metformin was reported to limit proliferation of breast cancer cells by acting upon specific micro (mi)RNAs (18-20). Treatment with metformin inhibits growth by enhancing the tumor suppressive function of TGF- $\beta$. This occurs as a result of metformin disrupting the TGF- $\beta /$ miRNA-181 signaling axis in cancer cells (21-23).

TGF- $\beta$ plays a central role in tumor inhibition by both aspirin and metformin. Not surprisingly, metformin and aspirin have synergistic effects and share several underlying mechanisms for controlling cancer (24-26). In the present study, we investigated the antitumor activity of aspirin and metformin mediated by the TGF- $\beta$ signaling pathway.

TGF- $\beta$ is a versatile cytokine intimately involved in cell growth (27-29). Depending on the tumor type and tissue context, it may act both as a tumor suppressor or a promoter of migration, invasion and tumor survival (30). Furthermore, TGF- $\beta$ can be regulated by estrogen (mainly estradiol) in vivo (31). Estrogen contributes to the inhibition of TGF- $\beta /$ Smad signaling by promoting R-Smad (Smad 2 and Smad3) degradation (31-34).

4T1 is a p53-deficient breast cancer cell line $(35,36)$. Triple-negative breast cancer cell lines [i.e., lacking the estrogen receptor (ER), progesterone receptor, and human epidermal growth factor receptor 2 (HER2)] are less affected by estrogen than traditional cell lines $(37,38)$. Accordingly, estrogen suppression treatment is usually not recommended in such cases, including in 4T1 cells. In the present study, we hypothesized that the lack of estrogen inhibition in triple-negative breast cancer cells may change the effect of aspirin and metformin on tumor growth inhibition in vivo by regulating TGF- $\beta$ activity. We also discuss the link between aspirin, metformin, TGF- $\beta 1$ and estradiol in murine breast cancer inhibition. 


\section{Materials and methods}

Cell culture and treatment. The mouse breast carcinoma cell line 4T1 was obtained from the American Type Culture Collection (ATCC; Manassas, VA, USA), and maintained at $37^{\circ} \mathrm{C}$ in a humidified condition of $95 \%$ air and $5 \% \mathrm{CO}_{2}$. Cells were cultured in $75 \mathrm{~cm}^{2}$ flasks or 6-well plates with Dulbecco's modified Eagle's medium (DMEM) (Life Technologies, Bedford, MA, USA) supplemented with $10 \%$ heat-inactivated fetal bovine serum (FBS), $100 \mathrm{U} / \mathrm{ml}$ penicillin, and $100 \mathrm{U} / \mathrm{ml}$ streptomycin. Before addition of aspirin, metformin, estradiol or LY364947, which is one of inhibitors of TGF $\beta$ R-I, cells are allowed to attach to the substrate for $24 \mathrm{~h}$. Aspirin, metformin, estradiol and LY364947 were purchased from Sigma-Aldrich (St. Louis, MO, USA).

For TGF- $\beta 1$ treatment, $0.01 \mu \mathrm{g} / \mathrm{ml}$ to $1 \times 10^{4} 4 \mathrm{~T} 1$ cells of human recombinant TGF- $\beta 1$ (BioLegend, Inc., San Diego, CA, USA) were used, and $0.01 \mu \mathrm{g} / \mathrm{ml}$ to $1 \times 10^{4} 4 \mathrm{~T} 1$ cells PBS as for the control group. For drug treatment group, nine groups were divided: i) $5 \mu \mathrm{M}$ aspirin; ii) $10 \mu \mathrm{M}$ metformin; iii) $5 \mu \mathrm{M}$ aspirin plus $10 \mu \mathrm{M}$ metformin; iv) $5 \mu \mathrm{M}$ aspirin with $1 \mu \mathrm{M}$ LY364947; v) $10 \mu \mathrm{M}$ metformin with $1 \mu \mathrm{M}$ LY364947; vi) combination of $5 \mu \mathrm{M}$ aspirin and $10 \mu \mathrm{M}$ metformin with $1 \mu \mathrm{M}$ LY364947; vii) $5 \mu \mathrm{M}$ aspirin plus $10 \mathrm{nM}$ estradiol; viii) $10 \mu \mathrm{M}$ metformin plus $10 \mathrm{nM}$ estradiol; and ix) combination of $5 \mu \mathrm{M}$ aspirin and $10 \mu \mathrm{M}$ metformin plus $10 \mathrm{nM}$ estradiol, the same amount of dimethyl sulfoxide (DMSO) as control group. Each group $(n=5)$ was treated for 24, 36 and $48 \mathrm{~h}$ before harvested for further study. The $\mathrm{N}$-values of cell experiments are three, respectively. The dose was based on literature $(26,39)$ and our earlier study, then we identified a roughly dose range. From the range in our results from the MTT assay, we chose the final dose.

The in vivo model. Five-week-old female BALB/c mice (Beijing HFK Bioscience Co., Ltd., Beijing, China) were used for the in vivo animal experiments. The animals were housed in constant laboratory conditions with a 12-h light/dark cycle and fed with water and food ad libitum. All animal care followed institutional guidelines under a protocol approved by the Institutional Animal Care and Use Committee of Sichuan University. Mice were subcutaneously inoculated into the rightback with $1 \times 10^{6} 4 \mathrm{~T} 1$ cells in $100 \mu \mathrm{l}$ PBS. For the treatment, the tumor-bearing mice were divided into groups, respectively: i) $100 \mu \mathrm{l}$ normal saline; ii) tamoxifen $(100 \mathrm{mg} / \mathrm{kg} / 24 \mathrm{~h})$; iii) aspirin (60 mg/kg/24 h); iv) metformin (160 mg/kg/24 h); v) aspirin and metformin; vi) aspirin with tamoxifen; vii) metformin with tamoxifen; viii) aspirin and metformin with tamoxifen. Each group had 5 mice. Metformin and tamoxifen were dissolved in normal saline through intragastric administration for 15 days. Aspirin was dissolved in ultrapure water with $4 \%$ ethanol as cosolvent through intraperitoneal injection for the same days. The mice with a tumor $(0.5-1.0 \mathrm{~cm}$ wide, and $0.5-1.0 \mathrm{~cm}$ long) were randomized and injected ( $\mathrm{n}=5 /$ group). The tumor volume $[0.5 \mathrm{x}$ [major axis] $\mathrm{x}$ [minor axis $]^{2}$ ] of every mouse was monitored every 2 days. Mice were sacrificed at day 15 , and samples were analyzed as previously described (40). All procedures regarding the care and use of animals followed the guidelines of and were approved by the Animal Ethics Committee of Sichuan University.
Cell proliferation assay. Cell proliferation was assessed using 3-(4,5-dimethylthiazol-2-yl)-2,5-diphenyltetrazolium bromide (MTT) assay. Cells were seeded into 96-well plates and cultured for 24, 36 and $48 \mathrm{~h}$ following by addition of MTT solution to the cells for $4 \mathrm{~h}$. After removing the medium, the remaining MTT formazan crystals were solubilized in DMSO and measured at $560 \mathrm{~nm}$ using a microplate reader (Benchmark Electronics, Angleton, TX, USA).

ELISA. 4T1 tumors were collected and then homogenized in radioimmunoprecipitation assay (RIPA) buffer (0.1\% SDS, $0.5 \%$ deoxycholate, $1 \%$ Triton $\mathrm{X}-100,150 \mathrm{mM} \mathrm{NaCl}$ and $50 \mathrm{mM}$ Tris- $\mathrm{HCl}$ ), followed by centrifugation at $13,300 \mathrm{rpm}$ for $30 \mathrm{~min}$ at $4^{\circ} \mathrm{C}$. DEAB assay was used to test the protein concentration of samples. The prepared samples were stored at $-80^{\circ} \mathrm{C}$ until used. Levels of TGF- $\beta 1$ in the samples were assessed by mouse ELISA kits (eBioscience or R\&D Systems, Minneapolis, MN, USA) according to the manufacturer's instructions, and the colorimetric reaction was measured at $450 \mathrm{~nm}$, the color absorbance was recorded at $450 \mathrm{~nm}$ using a Spectra MAX M5 microplate spectrophotometer (Molecular Devices, Sunnyvale, CA, USA). The amount of TGF- $\beta 1$ secreted into the supernatant of 4T1 cells was quantified using the same ELISA kits.

Blood samples were collected from the eye socket and placed at room temperature for $3 \mathrm{~h}$ to obtain the serum. The serum levels of estradiol detected using ELISA kits (Yan Hui Biological Technology, Shanghai, China).

Flow cytometric analysis of apoptosis. 4T1 cells were treated as described above and then harvested, washed in cold phosphate-buffered saline (PBS), double-stained with fluorescein isothiocyanate (FITC)-conjugated Annexin V and propidium iodide (PI) (BD Biosciences, San Jose, CA, USA) and analyzed by flow cytometry (FACSAria SORP; BD Biosciences, Erembodegem, Belgium). Apoptosis assays were performed with FITC/PI as $\mathrm{FITC}^{+} / \mathrm{PI}^{-}$and $\mathrm{FITC}^{+} / \mathrm{PI}^{+}$to measure early and late apoptosis, respectively. PI is a cell viability marker and FITC an apoptosis marker.

Western blot analysis. 4T1 cells were harvested, lysed and total protein was quantified with Micro BCA Protein Assay kit (Pierce, Rockford, IL, USA). Total protein $(10 \mu \mathrm{g})$ from each sample was separated by electrophoresis using $12 \%$ SDS-PAGE gels, transferred onto polyvinylidene fluoride membranes (Merck Millipore, Billerica, MA, USA), blocked with 5\% skim milk, and incubated using the primary antibodies $(1: 1,000)$ against Mcl-1, Bax, Bcl-2, caspase-8, TGF- $\beta 1$, Smad2/3, $\mathrm{pSmad} 2, \mathrm{pSmad} 3, \operatorname{Smad} 4$ and $\beta$-actin overnight $(16 \mathrm{~h})$ at $4^{\circ} \mathrm{C}$. $\beta$-actin was used as a loading control. All primary antibodies were from Abcam Science Company (Cambridge, UK). Blots were then incubated with the corresponding secondary antibodies (1:10,000; Cell Signaling Technology, Danvers, MA, USA) for $1 \mathrm{~h}$ at room temperature. After exposed to ECL reagent (Merck Millipore) advanced luminescence, signals were developed on X-ray film (Kodak, Rochester, NY, USA), and performed as previously described (41).

Terminal deoxynucleotidyl transferase-mediated dUTP nick end-labeling (TUNEL) assay. For each sample, 5-mm sections 

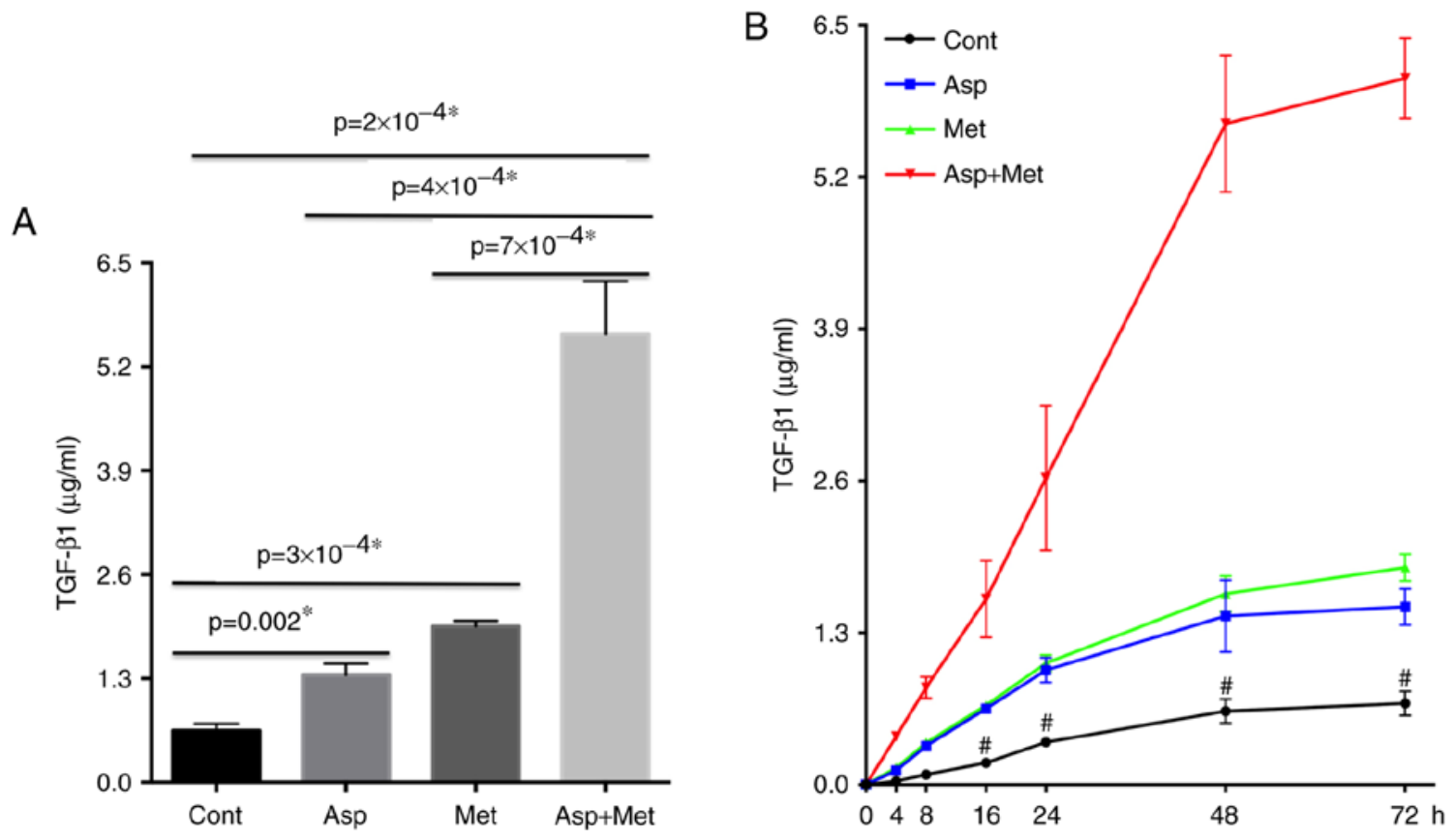

Figure 1. The combination of metformin (Met) and aspirin (Asp) promotes transforming growth factor (TGF)- $\beta 1$ in the supernatant fluid of 4T1 cells. The amounts of TGF- $\beta 1$ after a $48 \mathrm{~h}$ treatment and at different time points are shown; ${ }^{*} \mathrm{P}<0.05 \mathrm{vs}$. Asp, Met and the Asp + Met groups at the same time point. Cont, control.

of root tips were fixed using 4\% paraformaldehyde (\#18814; Polysciences, Inc., Warminster, PA, USA) in PBS for 45 min at room temperature. The fixation step was followed by a permeabilization step with $0.25 \%$ Triton X-100 in PBS for $20 \mathrm{~min}$ at room temperature. Next, terminal deoxynucleotidyl transferase-mediated dUTP (2'-deoxyuridine, 5'-triphosphate) nick end-labeling (TUNEL) assay was performed following the manufacturer's instructions $\left(\right.$ Click-iT $^{\circledR}$ TUNEL Alexa Fluor ${ }^{\circledR}$ Imaging Assay Protocol) and the nuclei were stained for $3 \mathrm{~min}$ with $0.3 \mathrm{mg} / \mathrm{ml}$ 4',6-diamidino-2-phenylindole (DAPI). Finally, the cells were mounted in Vectashield embedding medium (Vector Laboratories, Burlingame, CA, USA). All images were recorded at exactly the same time of integration using an AxioCam ERc5s CCD camera and AxioVision 4.8 software (both from Zeiss, Jena, Germany). Image processing was carried out in Adobe Photoshop 7.0 Adobe Systems, Inc., San Jose, CA, USA). Three samples worked each mouse and 10 visual fields were analyzed for each sample.

Statistical analysis. Data are expressed as mean \pm standard deviation (SD). Analysis of variation (ANOVA) were used for the statistical analysis, and $\mathrm{P}<0.05$ was considered statistically significant. All statistics were performed using SAS 9.2.

\section{Results}

Aspirin combined with metformin increases secretion of $T G F-\beta 1$ by $4 T 1$ cells. Following treatment with aspirin and metformin for at least $48 \mathrm{~h}$, we detected increased TGF- $\beta 1$ secretion and consequent tumor growth inhibition in $4 \mathrm{~T} 1$ cells. Next, we used ELISA to measure the amount of TGF- $\beta 1$ in the supernatant of $4 \mathrm{~T} 1$ cells after the different treatments (Fig. 1A). TGF- $\beta 1$ levels were maximal following combined aspirin and metformin treatment. Additionally, TGF- $\beta 1$ secretion was proportional to the length of the treatment, in spite of slower growth after $48 \mathrm{~h}$ (Fig. 1B). This led us to conclude that aspirin and metformin stimulated the secretion of TGF- $\beta 1$. More importantly, the combination of aspirin and metformin had a synergistic effect on TGF- $\beta 1$ secretion.

TGF- $\beta 1$ reduces cell viability and induces apoptosis in $4 T 1$ cells. To evaluate the effect of TGF- $\beta 1$ on proliferation and apoptosis in 4T1 cells, we used the MTT assay with different concentrations of TGF- $\beta 1$ (Fig. $2 \mathrm{~A}$ ). We observed that, within a certain range, TGF- $\beta 1$ reduced $4 \mathrm{~T} 1$ cell viability. We then used flow cytometry to assess apoptosis of $4 \mathrm{~T} 1$ cells following treatment with $100 \mathrm{ng} / \mathrm{ml}$ TGF- $\beta 1,1 \mu \mathrm{M}$ LY364947 (a TGF- $\beta$ type I receptor inhibitor), or $10 \mathrm{nM}$ estradiol (Fig. 2B). The results indicated that, depending on the concentration, TGF- $\beta 1$ induced both early and late apoptosis in 4T1 cells. PI is a cell viability marker and FITC an apoptosis marker, of early apoptosis is $\mathrm{PI}^{-} / \mathrm{FITC}^{+}$and late apoptosis $\mathrm{PI}^{+} / \mathrm{FITC}^{+}$.

Aspirin and metformin reduce cell viability and induce apoptosis in $4 T 1$ cells. To evaluate whether different concentrations of aspirin and metformin had a synergistic effect on the proliferation of $4 \mathrm{~T} 1$ cells, we performed the MTT assay. Combined treatment with these drugs led to a synergistic inhibition of cell viability, notably at $5 \mu \mathrm{M}$ aspirin and $10 \mu \mathrm{M}$ metformin ( $\mathrm{P}=0.002)$ (Fig. 3A). Next, we assessed the expression of apoptosis-related proteins. Western blotting revealed increased levels of Bcl-2 and caspase-8 (p18), and decreased levels of Bax and Mcl-1 following a 48-h treatment with aspirin and/or metformin. Changes were notable after combined treatment (Fig. 3B). To determine whether apoptotic cell death occurred, we evaluated cells by flow cytometry using co-staining with FITC and PI (Fig. 3C). The results 

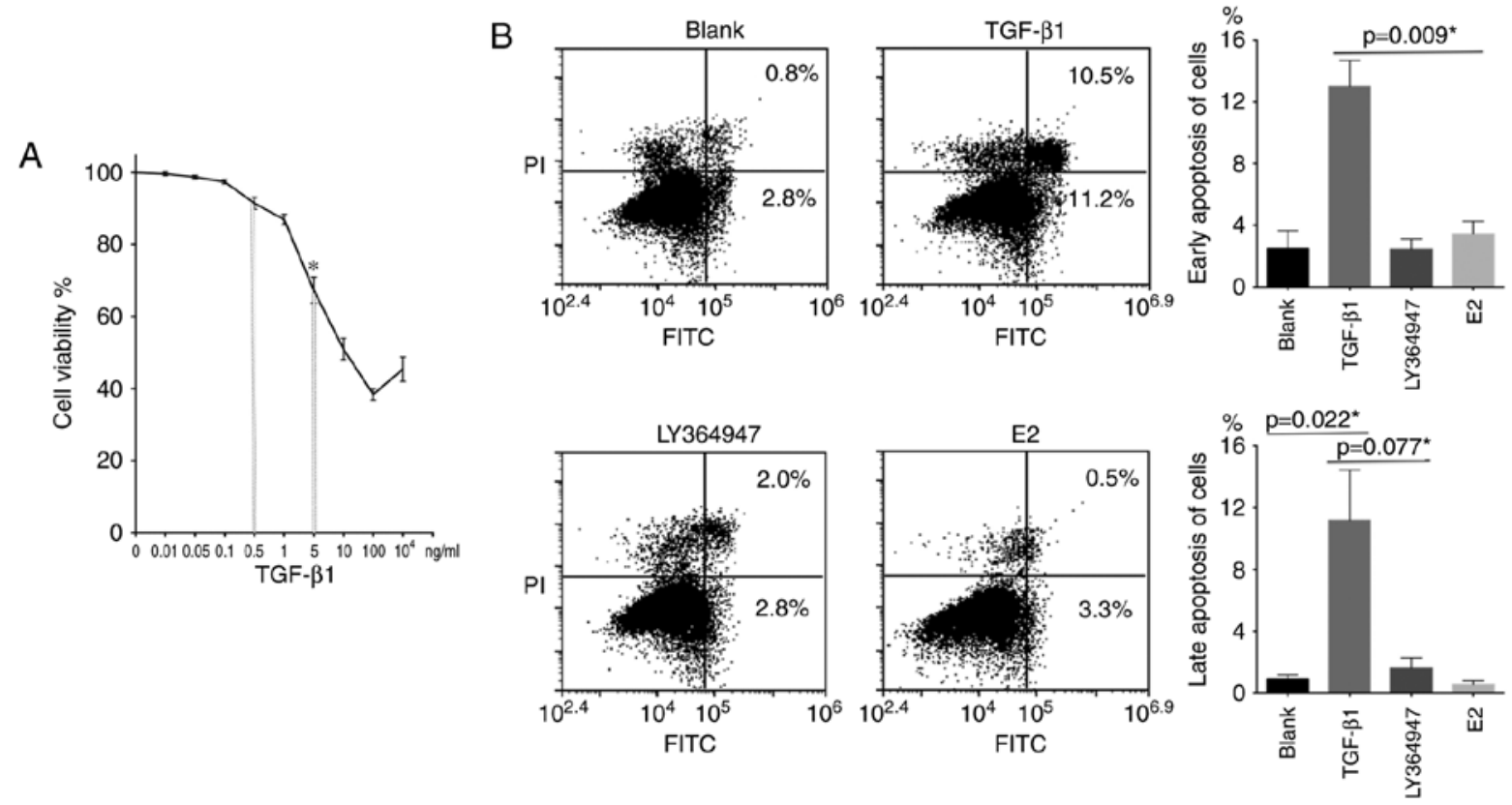

Figure 2. Effects of transforming growth factor (TGF)- $\beta 1$ on $4 \mathrm{~T} 1$ cell viability. (A) $4 \mathrm{~T} 1$ cells were exposed to different concentrations of TGF- $\beta 1$ for $48 \mathrm{~h}$ $(\mathrm{P}<0.05$ for $0.5 \mathrm{vs.} 5 \mu \mathrm{g} / \mathrm{ml}$ ). (B) Apoptosis was assessed in $4 \mathrm{~T} 1$ cells after treatment with $100 \mathrm{ng} / \mathrm{ml} \mathrm{TGF}-\beta 1,1 \mu \mathrm{M}$ LY364947 or $10 \mathrm{nM}$ estradiol for $48 \mathrm{~h}$.

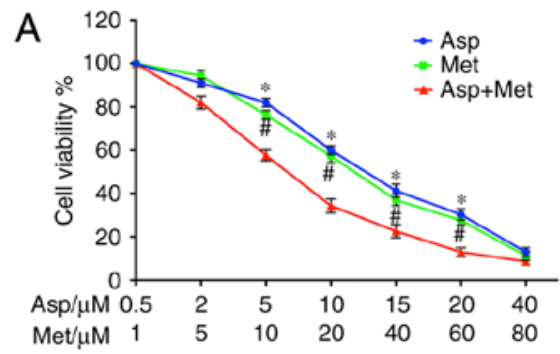

${ }^{*} \mathrm{P}<0.05$, Asp vs. Asp+Met at the same time point; \# $\mathrm{P}<0.05$, Met vs. Asp + Met at the same time point.

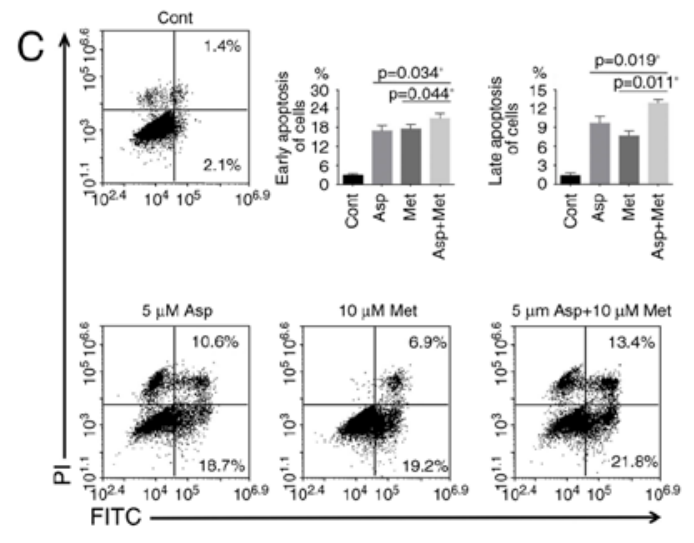

B

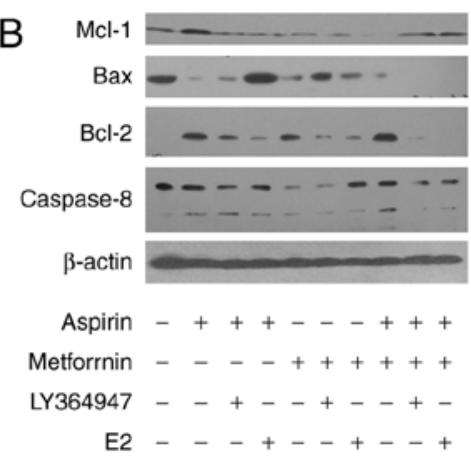

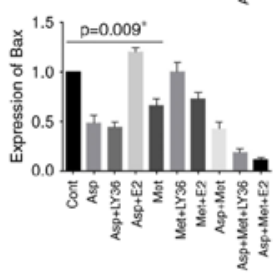
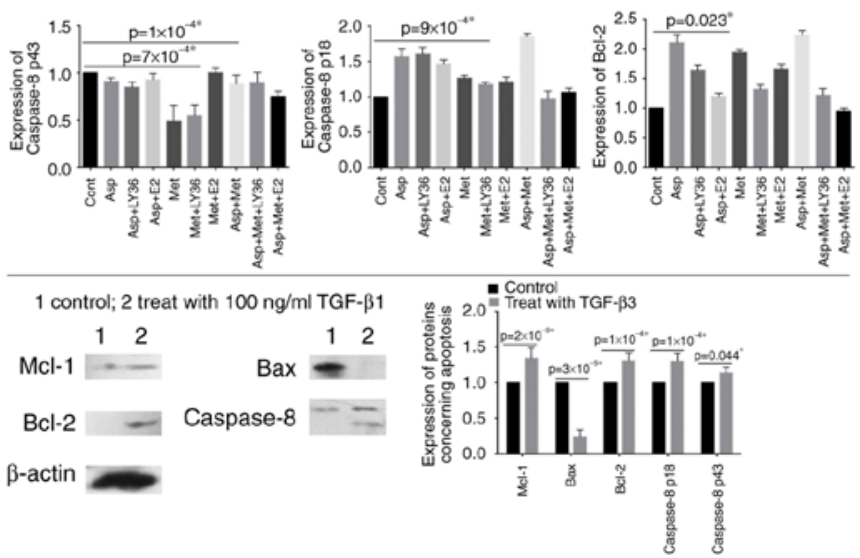

Figure 3. Effects of aspirin (Asp) and metformin (Met) on 4T1 cells. (A) 4T1 cells were treated with aspirin and metformin at the indicated concentrations for $48 \mathrm{~h}$. Cell viability was evaluated by the MTT assay. " $\mathrm{P}<0.05$ vs. the Asp and Met groups at the same concentrations; ${ }^{*} \mathrm{P}<0.05$ vs. the Asp and Met groups at the same concentrations. (B) Regulation of proteins affecting apoptosis. Protein levels were detected by western blotting. $\beta$-Actin was used as the loading control. (C) 4T1 cells were stained with Annexin V-FITC and propidium iodide following treatment with or without $10 \mu \mathrm{M}$ metformin or $5 \mu \mathrm{M}$ aspirin for $48 \mathrm{~h}$. Apoptosis was determined by flow cytometry. Cont, control.

showed that aspirin and metformin decreased cell viability and induced apoptosis in 4T1 cells, with the combined treatment having the strongest effect.
Aspirin and metformin enhance the TGF- $\beta$-dependent pathway to promote suppression of $4 T 1$ cells, whereas estradiol weakens the effect. Given that secretion of TGF- $\beta 1$ 

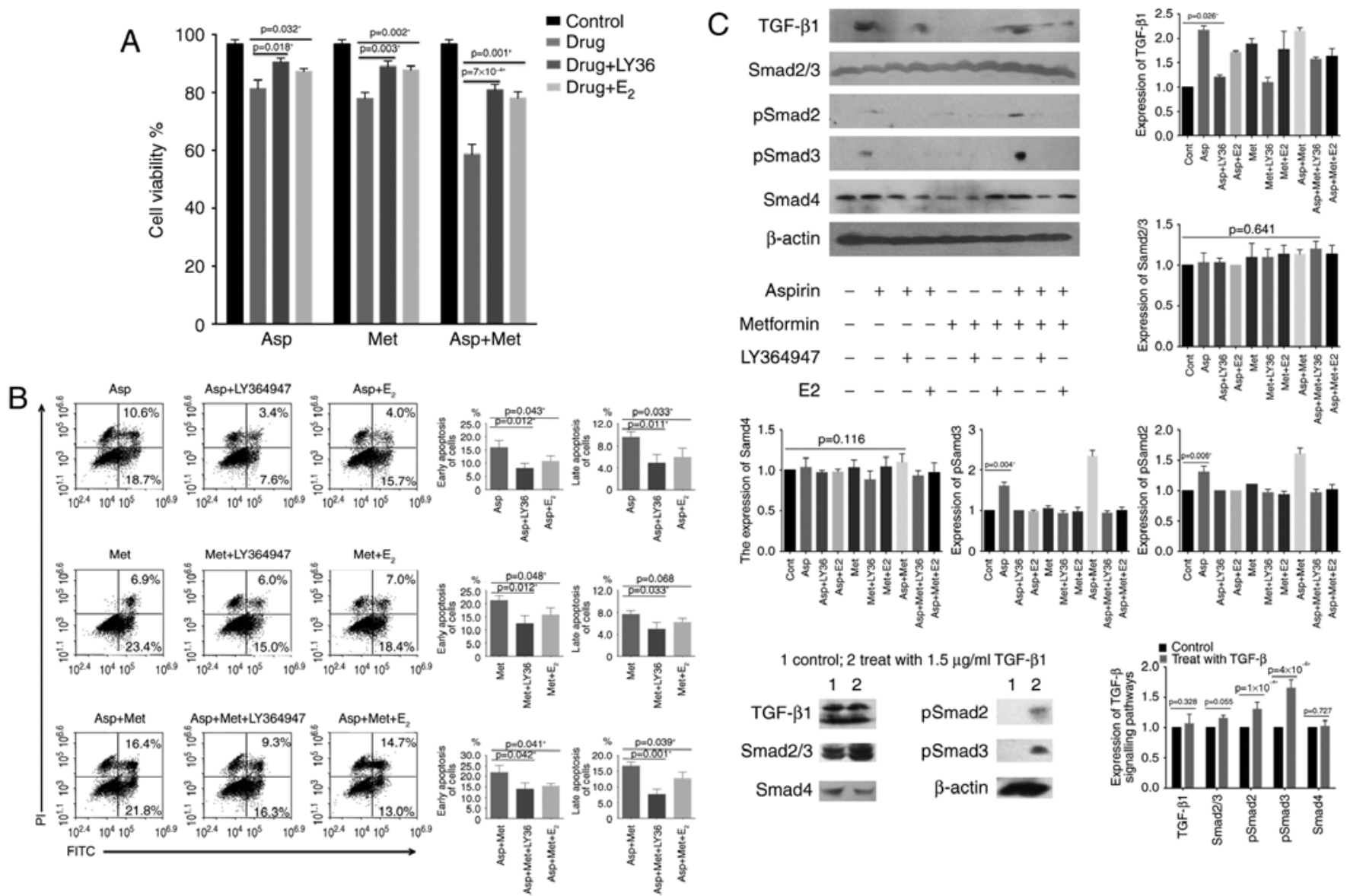

Figure 4. Aspirin and metformin enhance transforming growth factor (TGF)- $\beta$ dependent pathways to suppress 4T1 cells, but estradiol weakens the suppression. (A) 4T1 cells were treated with different concentrations of aspirin (Asp) and metformin (Met) for $48 \mathrm{~h}$. Cell viability was evaluated by the MTT assay.

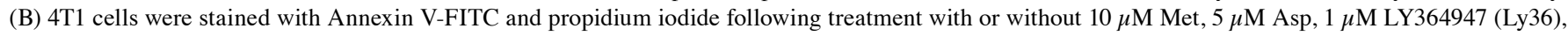
or $10 \mathrm{nM}$ estradiol (E2) for $48 \mathrm{~h}$. Apoptosis was determined by flow cytometry. (C) Regulation of the TGF- $\beta$ signaling pathway. Levels of TGF- $\beta$ signaling pathway proteins were detected by western blotting. $\beta$-Actin was used as the loading control. Cont, control.

by $4 \mathrm{~T} 1$ cells was a major finding of the present study, we decided to design an appropriate treatment. Results from the MTT assay (Fig. 3A) indicated that both drugs led to growth inhibition, as determined by a decrease in optical absorbance with $5 \mu \mathrm{M}$ aspirin and $10 \mu \mathrm{M}$ metformin. We used LY364947 to block the TGF- $\beta 1$ receptor and observed an increase in optical density. A similar effect was seen with estradiol (Fig. 4A). Expression of apoptosis-related proteins decreased in 4T1 cells following addition of LY364947 and estradiol, in contrast to the pro-apoptotic effect of aspirin and metformin (Fig. 3B). These findings were confirmed by flow cytometry (Fig. 4B).

Once cells were no longer stimulated by TGF- $\beta 1$, growth inhibition was relieved, suggesting that the inhibition caused by aspirin was indeed mediated by TGF- $\beta 1$. To further determine whether the TGF- $\beta$-dependent pathway was involved in the induction of apoptosis by metformin and aspirin, we examined the effect of the two drugs on downstream targets of TGF- $\beta 1$ (Smad2, Smad3 and Smad4). Treatment with $100 \mathrm{ng} / \mathrm{ml}$ TGF- $\beta 1$ (Fig. 4C) was used for comparison. The phosphorylation of Smad2 and Smad3 was significantly stronger in cells treated with a combination of metformin and aspirin whereas treatment with aspirin or metformin alone had only a moderate or small effect, respectively. Accordingly, specific bands corresponding to phosphorylated Smad2 or Smad 3 were barely detectable once TGF- $\beta 1$ induction was suspended.

Aspirin and metformin inhibit growth of $4 T 1$ tumors in $B A L B / c$ mice. A combination of metformin and aspirin caused a strong inhibitory effect on tumor growth in vivo, whereas aspirin or metformin alone had only a mild inhibitory effect. It should be noted that administration of tamoxifen with aspirin and metformin also had a significant inhibitory effect on tumor growth in vivo (Fig. 5A); tumor size in the group treated with all three agents was the smallest while the control group showed the largest tumor size. Tumor size in the aspirin plus metformin group was smaller than that in the aspirin or metformin alone groups.

The TUNEL assay was used to detect apoptosis in subcutaneously transplanted tumors in mice. This experiment revealed that the triple drug combination caused the most significant increase in apoptosis (Fig. 5B). After euthanasia, the amount of estradiol in the blood was measured (Fig. 5C). Based on these results, a lower estradiol content could mediate the strong inhibitory effect caused by a combination of aspirin and metformin. The amount of TGF- $\beta 1$ was greatest in subcutaneously transplanted tumors of mice subjected to a combined drug treatment (Fig. 5D). 
A

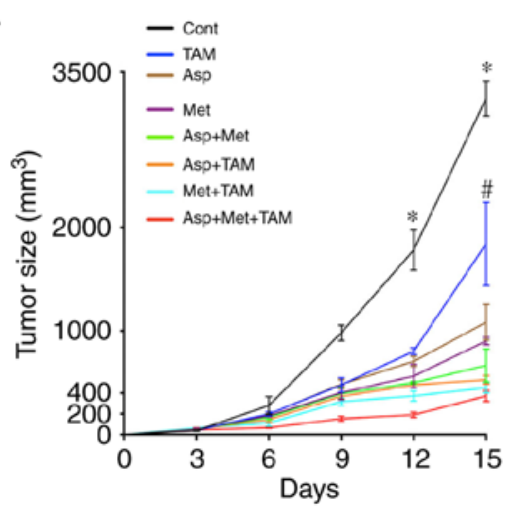

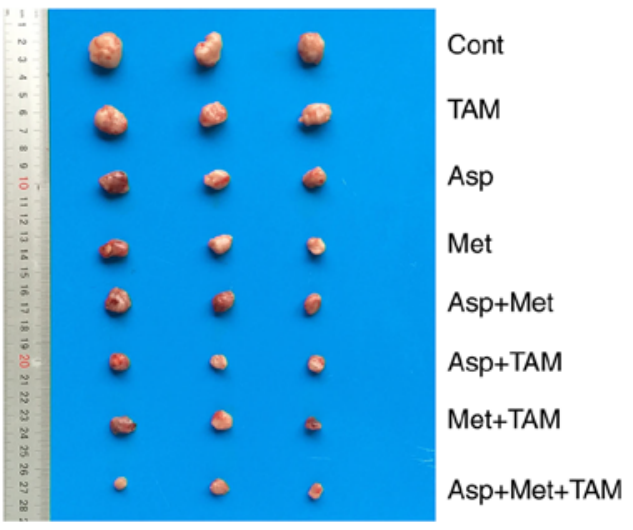

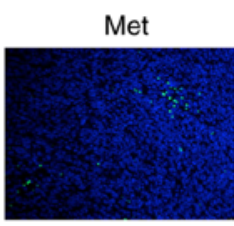

Asp+Met+TAM

Met+TAM
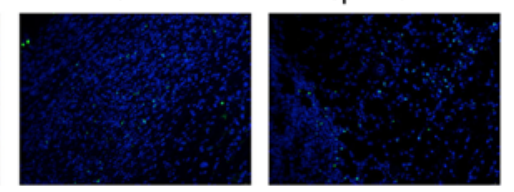

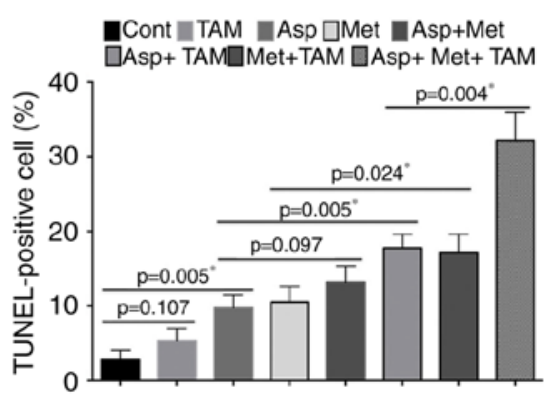

0
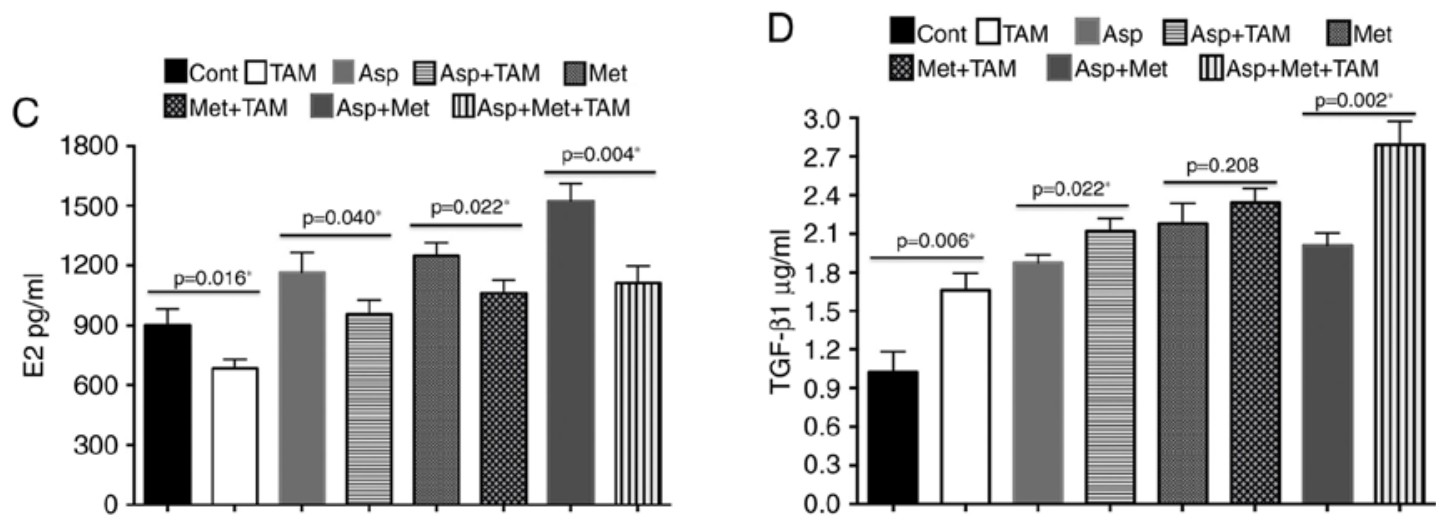

Figure 5. Tumor sizes after treatment of BALB/c mice with aspirin (Asp), metformin (Met) and tamoxifen (TAM). (A) The administration of TAM with Asp and Met significantly inhibited 4T1 tumor growth. Tumor size in the Asp + Met + TAM group is the smallest while that in control animals is the largest. Tumor size in the Asp + Met group is smaller than in the Asp and Met alone groups. The left panel shows changes of tumor volume in each group, and the right panel shows representative images of the tumors. Values are expressed as means $\pm \mathrm{SE}, \mathrm{n}=5 ;{ }^{*} \mathrm{P}<0.05$ vs. the TAM, Asp, Met, Asp + Met, Asp + TAM, Met + TAM and Asp + Met + TAM groups at the same time point; ${ }^{\text {PP}}<0.05$ vs. the Asp, Met, Asp + Met, Asp + TAM, Met + TAM and Asp + Met + TAM groups at the same time point. (B) Apoptosis assayed with TUNEL staining (magnification, x200). TUNEL (green) and DAPI (blue) merge. The control shows the least apoptosis while the Asp + Met + TAM group shows the most. (C) Serum levels of estradiol in 4T1 tumor-bearing mice. After 15 days of treatment, blood samples were collected from the eye socket and placed at room temperature for $3 \mathrm{~h}$ to obtain serum. Estradiol was detected using ELISA kits. (D) Asp + Met + TAM treatment increased transforming growth factor (TGF- $\beta 1$ ) levels in tumors. The DEAB assay was used to measure the protein concentration of samples. Levels of TGF- $\beta 1$ in the samples were assessed by ELISA kits. Cont, control.

\section{Discussion}

In the present study, we evaluated the effect of combining low doses of aspirin and metformin on the growth of 4T1 breast cancer cells in vitro and in vivo. We also highlighted the link between TGF- $\beta$ and estradiol in tumor apoptosis. A combination of aspirin and metformin showed synergistic cytotoxicity in 4T1 cells and a significant inhibitory effect on in vivo tumor growth through regulation of important apoptosis-related proteins, such as Bcl-2, Mcl-1, Bax, and caspase-8, and consequent cell death. A combination of the two drugs was notably effective at increasing TGF- $\beta 1$ levels in the supernatant fluid of 4T1 cells and in the blood of 4T1 tumor-bearing mice. Estradiol in 4T1 tumor-bearing mice weakened the antitumor effect of aspirin and metformin by downregulating TGF- $\beta 1$ and promoting Smad2 and Smad3 degradation in vivo.

To the best of our knowledge, this is the first study to show that the TGF- $\beta$ signaling pathway mediates the inhibitory effect of combined aspirin and metformin treatment on tumors. We reported previously that apoptosis of tumor tissue was induced and micro-vessel density was decreased after high-dose aspirin treatment, without any severe damage to the 
stomach, small intestine, liver and spleen (40). Epidemiological evidence has shown a consistent prophylactic effect of aspirin on breast cancer $(42,43)$. After 20 years of follow-up, overall cancer mortality has been shown to be decreased by $\sim 20 \%$ in people taking aspirin, with the greatest benefit for adenocarcinomas (36\% reduction) in randomized prevention trials $(44,45)$. In particular, aspirin has a significant effect on preventing colorectal cancer (46) and risk reduction (47).

Metformin therapy weakens the risk of glioma-initiating cells (48), and inhibits ovarian cancer by increasing sensitivity to cisplatin $(49,50)$, endometrial cancer through changes in Ki-67 proliferation $(51-53)$, and breast cancer $(54,55)$ and non-small cell lung carcinomas $(56,57)$. Laboratory studies on breast cancer have shown that metformin increases the mean life span by $8 \%$ and mammary adenocarcinoma latency by $13.2 \%(\mathrm{P}<0.05)$ in HER $2 /$ neu mice $(58)$. In retrospective studies, long-term use of $\geq 40$ prescriptions ( $>5$ years) of metformin is associated with an improved adjusted odds ratio of developing breast cancer compared with no use (59).

In the present study, we observed that a combination of aspirin and metformin had a stronger inhibitory effect on $4 \mathrm{~T} 1$ cell proliferation than either drug alone. This effect depend on TGF- $\beta 1$, in which levels increased following aspirin and metformin treatment. Western blot results showed markedly increased pSmad 2 and $\mathrm{pSmad} 3$ levels in the recombinant TGF- $\beta 1$ group, and the combined aspirin and metformin group, but only a marginal increase in the aspirin alone group. Moreover, we showed that metformin combined with aspirin regulated apoptosis-related proteins, mimicking the effect of recombinant TGF- $\beta 1$ treatment. This resulted in decreased Mcl-1 and Bax, and increased Bcl-2 and caspase- 8 levels. No obvious increase in caspase-8 (p18) was detected following metformin treatment alone. Moreover, an increase in early and late apoptosis following TGF- $\beta$ addition was consistent with the above data.

$4 \mathrm{~T} 1$ cells were injected subcutaneously into BALB/c mice in vivo. Compared to aspirin or metformin alone, mice subjected to a combination of the two drugs showed the highest TGF- $\beta 1$ content, smallest tumor size, and highest degree of tumor cell apoptosis. These results suggested that a combination of aspirin and metformin could significantly inhibit 4T1 cell growth in vitro and in vivo by promoting autocrine/paracrine TGF- $\beta 1$ to regulate apoptosis-related proteins.

TGF- $\beta$ shows suppressive effects at the early stage of tumorigenesis, whereas tumor cells in advanced stages can avoid the antiproliferative effect and undergo tumorigenic progression in response to TGF- $\beta(60,61)$. In the present study, we report that aspirin and/or metformin stimulated TGF- $\beta 1$, which could then suppress survival of breast cancer cells and phosphorylation of Smad2 and Smad3. In vivo experiments revealed that, in tumor-bearing mice treated for a maximum of $72 \mathrm{~h}$ with aspirin and/or metformin, and sacrificed 15 days later when the tumor did not develop to an advanced stage, smaller sized tumors contained the most TGF- $\beta 1$. Whether TGF- $\beta$ secretion can also be induced by aspirin and/or metformin in advanced cancer, and what the ensuing effect may be, will be addressed in future studies.

It was reported earlier that treatment of an adenoma cell line with TGF- $\beta$ triggered an increase in COX-2, which led to growth inhibition and apoptosis-mediated cell death (62-64).
As a nonsteroidal anti-inflammatory drug and COX inhibitor, aspirin prevents breast tumorigenesis in humans (12). Inhibition of the Smad signaling pathways attenuates TGF- $\beta 1$ induced COX-2 expression (15). Thus, it is possible that the Smad signaling pathway mediates TGF- $\beta$-induced COX- 2 by producing feedback inhibitory effects. There are some reports that metformin weakens the effect of TGF- $\beta 1$ or inhibits the TGF- $\beta$ pathway in normal cells $(65,66)$ or some metastatic tumor cells $(67,68)$ that differ from 4 T1 cells. TGF- $\beta$ plays different roles in different tumor stages (27-30). Thus, the different states of experimental cells may cause these different findings. It also has been shown that metformin increases nuclear p53 and TGF- $\beta 1$ levels in human breast cancer cell lines (69) and the metformin-mediated stimulation of TGF- $\beta 1$ secretion by mesangial cells is dose-dependent (70).

Tamoxifen, the mainstay of endocrine therapy for breast cancer, acts as a competitive inhibitor of the ER (71). It blocks the feedback loop of TGF- $\beta$ signaling $(72,73)$ by recruiting the N-CoR-histone deacetylase complex to the promoter (74-76). Binding of estrogen to the ER promotes formation of a multiprotein complex including N-CoR-histone deacetylase that removes acetyl groups and turns off transcription (77-79). Estrogen can reduce the expression of more than two-thirds of the genes induced by TGF- $\beta$ treatment (33). Consistent with this, we believe that estradiol from female BALB/c mice could attenuate the growth inhibition induced by aspirin and metformin by downregulating TGF- $\beta 1$. In vitro, we observed that, during early and late apoptosis, the levels of Bcl-2 and caspase- 8 were further decreased by simultaneous treatment with estradiol and aspirin or metformin, compared to aspirin or metformin alone. Inhibitors of the TGF- $\beta$ receptor produced a similar outcome. In vivo, the combination of aspirin, metformin, and tamoxifen led to the highest level of TGF- $\beta 1$, smallest tumor size, greatest degree of apoptosis in tumors, and the least estradiol in peripheral blood.

In conclusion, a combination of aspirin and metformin exhibits a synergetic cytotoxic effect in 4T1 breast cancer cells in vitro, and a significant inhibitory effect on $4 \mathrm{~T} 1$ tumor growth in vivo. In addition, inhibition of estrogen further maximizes antitumor activity of the combined drug treatment in vivo. However, according to the National Comprehensive Cancer Network Clinical Practice Guidelines in Oncology (80), patients with triple-negative breast cancer are not recommended for estrogen suppression treatment. The present study provides a rationale for clinical trials that combine aspirin with metformin, and brings attention to the link between estrogen levels and the outcome in triple-negative breast cancer patients.

\section{References}

1. Berstein LM: Metformin in obesity, cancer and aging: Addressing controversies. Aging) 4: 320-329, 2012.

2. Menendez JA, Oliveras-Ferraros C, Cufi S, Corominas-Faja B, Joven J, Martin-Castillo B and Vazquez-Martin A: Metformin is synthetically lethal with glucose withdrawal in cancer cells. Cell Cycle 11: 2782-2792, 2012.

3. Ma J, Guo Y, Chen S, Zhong C, Xue Y, Zhang Y, Lai X, Wei Y, Yu S, Zhang J and Liu W: Metformin enhances tamoxifenmediated tumor growth inhibition in ER-positive breast carcinoma. BMC Cancer 14: 172, 2014.

4. Currie CJ, Poole CD and Gale EA: The influence of glucose-lowering therapies on cancer risk in type 2 diabetes. Diabetologia 52: 1766-1777, 2009. 
5. Lee MS, Hsu CC, Wahlqvist ML, Tsai HN, Chang YH and Huang YC: Type 2 diabetes increases and metformin reduces total, colorectal, liver and pancreatic cancer incidences in Taiwanese: A representative population prospective cohort study of 800,000 individuals. BMC Cancer 11: 20, 2011.

6. Bodmer M, Becker C, Meier C, Jick SS and Meier CR: Use of antidiabetic agents and the risk of pancreatic cancer: A case-control analysis. Am J Gastroenterol 107: 620-626, 2012.

7. Niraula S, Dowling RJ, Ennis M, Chang MC, Done SJ, Hood N, Escallon J, Leong WL, McCready DR, Reedijk M, et al: Metformin in early breast cancer: A prospective window of opportunity neoadjuvant study. Breast Cancer Res Treat 135: $821-830,2012$

8. Cazzaniga M, DeCensi A, Pruneri G, Puntoni M, Bottiglieri L, Varricchio C, Guerrieri-Gonzaga A, Gentilini OD, Pagani G, Dell'Orto $\mathrm{P}$, et al: The effect of metformin on apoptosis in a breast cancer presurgical trial. Br J Cancer 109: 2792-2797, 2013.

9. Gronich N and Rennert G: Beyond aspirin-cancer prevention with statins, metformin and bisphosphonates. Nat Rev Clin Oncol 10: 625-642, 2013.

10. Zannella VE, Dal Pra A, Muaddi H, McKee TD, Stapleton S, Sykes J, Glicksman R, Chaib S, Zamiara P, Milosevic M, et al: Reprogramming metabolism with metformin improves tumor oxygenation and radiotherapy response. Clin Cancer Res 19: 6741-6750, 2013

11. Ugurlucan M, Caglar IM, Caglar FN, Ziyade S, Karatepe O, Yildiz Y,Zencirci E, Ugurlucan FG, Arslan AH, Korkmaz S, et al: Aspirin: From a historical perspective. Recent Pat Cardiovasc Drug Discov 7: 71-76, 2012.

12. Half E, Tang XM, Gwyn K, Sahin A, Wathen K and Sinicrope FA: Cyclooxygenase- 2 expression in human breast cancers and adjacent ductal carcinoma in situ. Cancer Res 62: 1676-1681, 2002.

13. Williams CS, Mann M and DuBois RN: The role of cyclooxygenases in inflammation, cancer, and development. Oncogene 18: 7908-7916, 1999.

14. Ulrich CM, Bigler J and Potter JD: Non-steroidal anti-inflammatory drugs for cancer prevention: Promise, perils and pharmacogenetics. Nat Rev Cancer 6: 130-140, 2006.

15. Fang L, Chang HM, Cheng JC, Leung PC and Sun YP: TGF- $\beta 1$ induces COX-2 expression and PGE2 production in human granulosa cells through smad signaling pathways. J Clin Endocrinol Metab 99: E1217-1226, 2014.

16. Adler AI, Shaw EJ, Stokes T and Ruiz F; Guideline Development Group: Newer agents for blood glucose control in type 2 diabetes: Summary of NICE guidance. BMJ 338: b1668, 2009.

17. Nathan DM, Buse JB, Davidson MB, Ferrannini E, Holman RR, Sherwin R and Zinman B; American DiabetesAssociation; European Association for Study of Diabetes: Medical management of hyperglycemia in type 2 diabetes: A consensus algorithm for the initiation and adjustment of therapy: A consensus statement of the American diabetes association and the European association for the study of diabetes. Diabetes Care 32: 193-203, 2009.

18. Takahashi RU, Miyazaki H, Takeshita F, Yamamoto $\mathrm{Y}$, Minoura K, Ono M, Kodaira M, Tamura K, Mori M and Ochiya T: Loss of microRNA-27b contributes to breast cancer stem cell generation by activating ENPP1. Nat Commun 6: 7318, 2015.

19. Bacci M, Giannoni E, Fearns A, Ribas R, Gao Q, Taddei ML, Pintus G, Dowsett M, Isacke CM, Martin LA, et al: miR-155 drives metabolic reprogramming of $\mathrm{ER}^{+}$breast cancer cells following long-term estrogen deprivation and predicts clinical response to aromatase inhibitors. Cancer Res 76: 1615-1626, 2016.

20. Cabello P, Pineda B, Tormo E, Lluch A and Eroles P: The antitumor effect of metformin is mediated by miR-26a in breast cancer. Int J Mol Sci 17: E1298, 2016.

21. Dontu G, Abdallah WM, Foley JM, Jackson KW, Clarke MF, Kawamura MJ and Wicha MS: In vitro propagation and transcriptional profiling of human mammary stem/progenitor cells. Genes Dev 17: 1253-1270, 2003.

22. Charafe-Jauffret E, Ginestier C, Iovino F, Wicinski J, Cervera N, Finetti P, Hur MH, Diebel ME, Monville F, Dutcher J, et al: Breast cancer cell lines contain functional cancer stem cells with metastatic capacity and a distinct molecular signature. Cancer Res 69: 1302-1313, 2009.
23. Oliveras-Ferraros C, Cufi S, Vazquez-Martin A, TorresGarcia VZ, Del Barco S, Martin-Castillo B and Menendez JA: Micro(mi)RNA expression profile of breast cancer epithelial cells treated with the anti-diabetic drug metformin: Induction of the tumor suppressor miRNA let-7a and suppression of the TGF $\beta$-induced oncomiR miRNA-181a. Cell Cycle 10: 1144-1151, 2011 .

24. Dowling RJ,Zakikhani M,Fantus IG, Pollak M and Sonenberg N: Metformin inhibits mammalian target of rapamycin-dependent translation initiation in breast cancer cells. Cancer Res 67: 10804-10812, 2007.

25. Din FV, Valanciute A, Houde VP, Zibrova D, Green KA, Sakamoto K, Alessi DR and Dunlop MG: Aspirin inhibits mTOR signaling, activates AMP-activated protein kinase, and induces autophagy in colorectal cancer cells. Gastroenterology 142: 1504-1515.e3, 2012

26. Yue W, Zheng X, Lin Y, Yang CS, Xu Q, Carpizo D, Huang H, DiPaola RS and Tan XL: Metformin combined with aspirin significantly inhibit pancreatic cancer cell growth in vitro and in vivo by suppressing anti-apoptotic proteins Mcl-1 and Bcl-2. Oncotarget 6: 21208-21224, 2015.

27. Blobe GC, Schiemann WP and Lodish HF: Role of transforming growth factor beta in human disease. N Engl J Med 342: 1350-1358, 2000.

28. Govinden R and Bhoola KD: Genealogy, expression, and cellular function of transforming growth factor-beta. Pharmacol Ther 98: 257-265, 2003

29. Reddi AH: BMPs: From bone morphogenetic proteins to body morphogenetic proteins. Cytokine Growth Factor Rev 16: 249-250, 2005

30. Joshi A and Cao D: TGF-beta signaling, tumor microenvironment and tumor progression: The butterfly effect. Front Biosci 15: 180-194, 2010.

31. Maurya VK, Jha RK, Kumar V, Joshi A, Chadchan S, Mohan JJ and Laloraya M: Transforming growth factor-beta 1 (TGF-B1) liberation from its latent complex during embryo implantation and its regulation by estradiol in mouse. Biol Reprod 89: 84, 2013.

32. Dixon A and Maric C: 17beta-Estradiol attenuates diabetic kidney disease by regulating extracellular matrix and transforming growth factor-beta protein expression and signaling. Am J Physiol Renal Physiol 293: F1678-F1690, 2007.

33. Ito I, Hanyu A, Wayama M, Goto N, Katsuno Y, Kawasaki S, Nakajima Y, Kajiro M, Komatsu Y, Fujimura A, et al: Estrogen inhibits transforming growth factor beta signaling by promoting Smad2/3 degradation. J Biol Chem 285: 14747-14755, 2010.

34. Li YC, Ding XS, Li HM, Zhang Y and Bao J: Role of $G$ protein-coupled estrogen receptor 1 in modulating transforming growth factor- $\beta$ stimulated mesangial cell extracellular matrix synthesis and migration. Mol Cell Endocrinol 391: 50-59, 2014.

35. Garijo R, Hernández-Alonso P, Rivas C, Diallo JS and Sanjuán R: Experimental evolution of an oncolytic vesicular stomatitis virus with increased selectivity for p53-deficient cells. PLoS One 9: e102365, 2014

36. Yerlikaya A, Okur E, Baykal AT, Acilan C, Boyaci I and Ulukaya E: A proteomic analysis of p53-independent induction of apoptosis by bortezomib in 4T1 breast cancer cell line. J Proteomics 113: 315-325, 2015

37. Saji S, Honma N, Hirose M, Hayashi S and Kuroi K: Translational cell study exploring the role of estrogen receptor beta expression as a predictive and/or prognostic factor in breast cancer patients. J Clin Oncol 27: e22185, 2009.

38. Wiggins AK, Kharotia S, Mason JK and Thompson LU: $\alpha$-Linolenic acid reduces growth of both triple negative and luminal breast cancer cells in high and low estrogen environments. Nutr Cancer 67: 1001-1009, 2015.

39. O'Brien AJ, Villani LA, Broadfield LA, Houde VP, Galic S, Blandino G, Kemp BE, Tsakiridis T, Muti P and Steinberg GR: Salicylate activates AMPK and synergizes with metformin to reduce the survival of prostate and lung cancer cells ex vivo through inhibition of de novo lipogenesis. Biochem J 469: 177-187, 2015.

40. Wang Y, Du C, Zhao M, Li M, Zhang N, Liu Y, Wang J and Luo F: Treatment of colonic transplantation tumor-bearing mice with a high-dose aspirin in a short period of time. Int J Colorectal Dis 31: 1099-1100, 2016.

41. Wang Y, Jiang M, Li Z, Wang J, Du C, Yanyang L, Yu Y, Wang X, Zhang N, Zhao M, et al: Hypoxia and TGF- $\beta 1$ lead to endostatin resistance by cooperatively increasing cancer stem cells in A549 transplantation tumors. Cell Biosci 5: 72, 2015. 
42. Cuzick J, Otto F, Baron JA, Brown PH, Burn J, Greenwald P, Jankowski J, La Vecchia C, Meyskens F, Senn HJ and Thun M: Aspirin and non-steroidal anti-inflammatory drugs for cancer prevention: An international consensus statement. Lancet Oncol 10: 501-507, 2009.

43. Zhao YS, Zhu S, Li XW, Wang F, Hu FL, Li DD, Zhang WC and Li X: Association between NSAIDs use and breast cancer risk: A systematic review and meta-analysis. Breast Cancer Res Treat 117: 141-150, 2009.

44. Rothwell PM, Fowkes FG, Belch JF, Ogawa H, Warlow CP and Meade TW: Effect of daily aspirin on long-term risk of death due to cancer: Analysis of individual patient data from randomised trials. Lancet 377: 31-41, 2011.

45. Rothwell PM, Wilson M, Price JF, Belch JF, Meade TW and Mehta Z: Effect of daily aspirin on risk of cancer metastasis: A study of incident cancers during randomised controlled trials. Lancet 379: 1591-1601, 2012

46. Chan AT, Arber N, Burn J, Chia WK, Elwood P, Hull MA, Logan RF, Rothwell PM, Schrör K and Baron JA: Aspirin in the chemoprevention of colorectal neoplasia: An overview. Cancer Prev Res 5: 164-178, 2012.

47. Algra AM and Rothwell PM: Effects of regular aspirin on long-term cancer incidence and metastasis: A systematic comparison of evidence from observational studies versus randomised trials. Lancet Oncol 13: 518-527, 2012.

48. Sato A, Sunayama J, Okada M, Watanabe E, Seino S, Shibuya K, Suzuki K, Narita Y, Shibui S, Kayama T and Kitanaka C: Glioma-initiating cell elimination by metformin activation of FOXO3 via AMPK. Stem Cells Transl Med 1: 811-824, 2012.

49. Shank JJ, Yang K, Ghannam J, Cabrera L, Johnston CJ, Reynolds RK and Buckanovich RJ: Metformin targets ovarian cancer stem cells in vitro and in vivo. Gynecol Oncol 127: 390-397, 2012.

50. Lengyel E, Litchfield LM, Mitra AK, Nieman KM, Mukherjee A, Zhang Y, Johnson A, Bradaric M, Lee W and Romero IL: Metformin inhibits ovarian cancer growth and increases sensitivity to paclitaxel in mouse models. Am J Obstet Gynecol 212: 479.e471-479.e10, 2015.

51. Cantrell LA, Zhou C, Mendivil A, Malloy KM, Gehrig PA and Bae-Jump VL: Metformin is a potent inhibitor of endometrial cancer cell proliferation-implications for a novel treatment strategy. Gynecol Oncol 116: 92-98, 2010.

52. Mitsuhashi A, Kiyokawa T, Sato Y and Shozu M: Effects of metformin on endometrial cancer cell growth in vivo: A preoperative prospective trial. Cancer 120: 2986-2995, 2014.

53. Sivalingam VN, Kitson S, McVey R, Roberts C, Pemberton P, Gilmour K, Ali S, Renehan AG, Kitchener HC and Crosbie EJ: Measuring the biological effect of presurgical metformin treatment in endometrial cancer. Br J Cancer 114: 281-289, 2016.

54. Bowker SL, Lin M, Eurich DT and Johnson JA: Time-varying risk for breast cancer following initiation of glucose-lowering therapy in women with type 2 diabetes: Exploring detection bias. Can J Diabetes 41: 204-210, 2017.

55. Rico M, Baglioni M, Bondarenko M, Laluce NC, Rozados V, André N, Carré M, Scharovsky OG and Menacho Márquez M: Metformin and propranolol combination prevents cancer progression and metastasis in different breast cancer models. Oncotarget 8: 2874-2889, 2017.

56. Gagnon B, Roseman M, Kasymjanova G, MacDonald N, Kreisman $\mathrm{H}$ and Small D: Protective effect of metformin in lung cancer patients. J Clin Oncol 27: e22063, 2009.

57. Storozhuk Y, Hopmans SN, Sanli T, Barron C, Tsiani E, Cutz JC, Pond G, Wright J, Singh G and Tsakiridis T: Metformin inhibits growth and enhances radiation response of non-small cell lung cancer (NSCLC) through ATM and AMPK. Br J Cancer 108: 2021-2032, 2013.

58. Anisimov VN, Egormin PA, Piskunova TS, Popovich IG, Tyndyk ML, Yurova MN, Zabezhinski MA, Anikin IV, Karkach AS and Romanyukha AA: Metformin extends life span of HER-2/neu transgenic mice and in combination with melatonin inhibits growth of transplantable tumors in vivo. Cell Cycle 9: 188-197, 2010

59. Bodmer M, Meier C, Krähenbühl S, Jick SS and Meier CR: Long-term metformin use is associated with decreased risk of breast cancer. Diabetes Care 33: 1304-1308, 2010.

60. Inman GJ: Switching TGF $\beta$ from a tumor suppressor to a tumor promoter. Curr Opin Genet Dev 21: 93-99, 2011.
61. Meulmeester E and Ten Dijke P: The dynamic roles of TGF- $\beta$ in cancer. J Pathol 223: 205-218, 2011.

62. Sheng H, Shao J, Hooton EB, Tsujii M, DuBois RN and Beauchamp RD: Cyclooxygenase-2 induction and transforming growth factor beta growth inhibition in rat intestinal epithelial cells. Cell Growth Differ 8: 463-470, 1997.

63. Sheng H, Shao J, O'Mahony CA, Lamps L, Albo D, Isakson PC, Berger DH, DuBois RN and Beauchamp RD: Transformation of intestinal epithelial cells by chronic TGF-betal treatment results in downregulation of the type II TGF-beta receptor and induction of cyclooxygenase-2. Oncogene 18: 855-867, 1999.

64. Crew TE, Elder DJ and Paraskeva C: A cyclooxygenase-2 (COX-2) selective non-steroidal anti-inflammatory drug enhances the growth inhibitory effect of butyrate in colorectal carcinoma cells expressing COX-2 protein: Regulation of COX-2 by butyrate. Carcinogenesis 21: 69-77, 2000.

65. Xiao H, Ma X, Feng W, Fu Y, Lu Z, Xu M, Shen Q, Zhu Y and Zhang Y: Metformin attenuates cardiac fibrosis by inhibiting the TGFbeta1-Smad3 signalling pathway. Cardiovasc Res 87: 504-513, 2010

66. Fan K, Wu K, Lin L, Ge P, Dai J, He X, Hu K and Zhang L: Metformin mitigates carbon tetrachloride-induced TGF- $\beta 1 /$ Smad3 signaling and liver fibrosis in mice. Biomed Pharmacother 90: 421-426, 2017.

67. Cheng K and Hao M: Metformin inhibits TGF- $\beta 1$-induced epithelial-to-mesenchymal transition via PKM2 relativemTOR/p70s6k signaling pathway in cervical carcinoma cells. Int J Mol Sci 17: E2000, 2016.

68. Leonel C, Borin TF, de Carvalho Ferreira L, Moschetta MG, Bajgelman MC, Viloria-Petit AM and de Campos Zuccari DA: Inhibition of epithelial-mesenchymal transition and metastasis by combined TGFbeta knockdown and metformin treatment in a canine mammary cancer xenograft model. J Mammary Gland Biol Neoplasia 22: 27-41, 2017.

69. Marinello PC, da Silva TN, Panis C, Neves AF, Machado KL, Borges FH, Guarnier FA, Bernardes SS, de-Freitas-Junior JC, Morgado-Díaz JA, et al: Mechanism of metformin action in MCF-7 and MDA-MB-231 human breast cancer cells involves oxidative stress generation, DNA damage, and transforming growth factor $\beta 1$ induction. Tumour Biol 37: 5337-5346, 2016.

70. Cortes P, Riser BL, Asano K, Rodríguez-Barbero A, Narins RG and Yee J: Effects of oral antihyperglycemic agents on extracellular matrix synthesis by mesangial cells. Kidney Int 54: 1985-1998, 1998

71. Kuiper GG, Enmark E, Pelto-Huikko M, Nilsson S and Gustafsson JA: Cloning of a novel receptor expressed in rat prostate and ovary. Proc Natl Acad Sci USA 93: 5925-5930, 1996.

72. Schmierer B and Hill CS: TGFbeta-SMAD signal transduction: Molecular specificity and functional flexibility. Nat Rev Mol Cell Biol 8: 970-982, 2007.

73. Lönn P, Morén A, Raja E, Dahl M and Moustakas A: Regulating the stability of TGFbeta receptors and Smads. Cell Res 19: 21-35, 2009.

74. Luo K, Stroschein SL, Wang W, Chen D, Martens E, Zhou S and Zhou Q: The Ski oncoprotein interacts with the Smad proteins to repress TGFbeta signaling. Genes Dev 13: 2196-2206, 1999.

75. Nomura T, Khan MM, Kaul SC, Dong HD, Wadhwa R, Colmenares C, Kohno I and Ishi S: Ski is a component of the histone deacetylase complex required for transcriptional repression by Mad and thyroid hormone receptor. Genes Dev 13: 412-423, 1999

76. Stroschein SL, Wang W, Zhou S, Zhou Q and Luo K: Negative feedback regulation of TGF-beta signaling by the SnoN oncoprotein. Science 286: 771-774, 1999.

77. Heery DM, Kalkhoven E, Hoare S and Parker MG: A signature motif in transcriptional co-activators mediates binding to nuclear receptors. Nature 387: 733-736, 1997.

78. Torchia J, Rose DW, Inostroza J, Kamei Y, Westin S, Glass CK and Rosenfeld MG: The transcriptional co-activator $\mathrm{p} / \mathrm{CIP}$ binds CBP and mediates nuclear-receptor function. Nature 387: 677-684, 1997

79. Cheskis BJ, Greger JG, Nagpal S and Freedman LP: Signaling by estrogens. J Cell Physiol 213: 610-617, 2007.

80. Gradishar WJ, Anderson BO, Balassanian R, Blair SL, Burstein HJ, Cyr A, Elias AD, Farrar WB, Forero A, Giordano SH, et al: NCCN guidelines insights breast cancer, Version 1.2016. J Natl Compr Canc Netw 13: 1475-1485, 2015. 